\title{
BIOLOGICAL CONTROL OF FIRE BLIGHT IN PEAR ORCHARDS WITH A FORMULATION OF PANTOEA AGGLOMERANS STRAIN EH 24
}

\author{
Hatice Özaktan*; Tayyar Bora \\ Department of Plant Protection, Faculty of Agriculture, University of Ege, Bornova, Ýzmir, Turkey
}

Submitted: March 12, 2003; Approved: July 05, 2004.

\begin{abstract}
Biological control by using epiphytic bacteria against Erwinia amylovora has been considered as an alternative method for controlling the disease. Talc-based formulation of Pantoea agglomerans strain Eh-24 was applied at $30 \%$ and $100 \%$ bloom on two pear orchards which were selected from different locations in the Aegean Region in Turkey. Pear orchard trials were replicated for two years (1999 and 2000) in each place. Talc-based formulation of P. agglomerans strain Eh-24 was sprayed on pear trees which were naturally infected with E. amylovora. In the orchard trials conducted in 1999 and 2000, talc-based formulation of P. agglomerans strain Eh-24 reduced the percentage of blighted blossoms on pear orchards by $63 \%$ to $76 \%$, approximately. Copper oxychloride+maneb was less effective in reducing the incidence of blossom infection by $E$. amylovora in each pear orchard than the bioformulation treatment. P. agglomerans strain Eh-24 labelled with Str ${ }^{\mathrm{R}+}$ was applied at $30 \%$ and $100 \%$ bloom to monitor the colonization and population dynamics of $P$. agglomerans on pear blossoms. The population size of P. agglomerans strain Eh-24 ${ }^{\text {strR+ }}$ on pear blossoms increased from $2 \times 10^{4}$ to $1.3 \times 10^{6} \mathrm{cfu}$ per blossom over 18 days.
\end{abstract}

Key words: biological control, fire blight, antagonistic bacteria, Pantoea agglomerans (Erwinia herbicola), Erwinia amylovora

\section{INTRODUCTION}

Fire blight caused by Erwinia amylovora has threatened pear cultivation in Turkey since 1985 (17). Suppression of the blossom-blight phase of fire blight is a key point in the management of this destructive and increasingly important disease of apple and pear (21). Chemical control of fire blight is difficult because there are few effective bactericides registered and streptomycin, which is effective, and other antibiotics are not registered worldwide. Additionally the pathogen, $E$. amylovora, has developed resistance to streptomycin in several important production areas $(8,14,25)$. Streptomycin also may be used as a medicine for therapeutical purposes, and concerns have arisen that use of streptomycin in orchards may lead to increased a risk of resistance of human pathogens to this antibiotic. The World Health Organization does not recommend its use in plant protection (28). Consequently, streptomycin is banned in Turkey for non-medical use. Copper sprays during flowering have been recommended for fire blight control, but these treatments often cause undesirable phytotoxic effects on blossoms and fruits $(14,24,29)$.

Alternative control strategies are urgently needed for fire blight. Biological control with epiphytic bacteria against E.amylovora has been considered as an potential method for controlling the disease (2). The bacterial strains belonging to the species Pantoea agglomerans (syn. Erwinia herbicola) and Pseudomonas fluorescens have been extensively studied as potential biological control agents of fire blight $(7,8,26,31)$. Spraying apple and pear blossoms with suspensions of $P$. agglomerans on occasion has given control of fire blight equivalent to that achieved with streptomycin (32).

Commercial use of antagonistic bacteria for control of fire blight depends upon the development of a formulation in which the bacteria can survive for a considerable length of time. One of the antagonists, P.fluorescens strain A506, is now available commercially as afreeze-dried formulation for biological control

*Corresponding author. Mailing address: University of Ege, Faculty of Agriculture, Department of Plant Protection. 35100 Bornova, İzmir, Turkey. Tel. (+90 232) 388-4000/1410. Fax (+90 232) 374-4848. E-mail: ozaktan@ziraat.ege.edu.tr 
of fire blight and frost injury in USA (Blight-Ban) (7). In the United States and New Zealand, several strains of P. agglomerans, are in various stages of commercial development (7).

In a previous research project, 167 epiphytic bacterial strains including $P$. agglomerans, fluorescent pseudomonads, and some Gram(+) bacteria were obtained from tissues of healthy pear trees in the Aegean Region. P. agglomerans strains Eh-24 and $1 \mathrm{~B}$ significantly reduced the percentage of blighted blossoms in the pear blossom assay by $82 \%$ to $98 \%$ compared to the untreated control (18).

The objectives of this research were to develop a talc-based formulation of $P$. agglomerans strain Eh-24, to investigate the capacity of bioformulation to control infection of blossoms by E. amylovora under commercial pear orchard conditions, and to monitor colonization of pear blossoms by P. agglomerans strain Eh-24.

\section{MATERIALSAND METHODS}

\section{Antagonistic Bacterium}

Approximately 167 bacterial strains were screened for biological control potential using the pear slice assay and detached blossom assay (10). P. agglomerans strain Eh-24, which was isolated from healthy pear blossoms in Ýzmir province was the most effective strain by preventing the pathogen at rate $100 \%$ on pear slices and $85 \%$ on detached pear blossoms (18).

Development of Bioformulation of $P$. agglomerans strain Eh-24

P. agglomerans strain Eh- 24 was grown at $24^{\circ} \mathrm{C}$ for 20 hours in sucrose $(5 \%)$ nutrient broth medium on a rotary shaker at 150 $\mathrm{rpm}$. Bacterial suspension was centrifuged for $20 \mathrm{~min}$ at 6.000 rpm. Bacterial pellet was resuspended in $0.1 \mathrm{M} \mathrm{MgSO}_{4}$ in a $1: 1(\mathrm{w} /$ v) ratio and then combined with either. $15 \%(\mathrm{v} / \mathrm{v})$ glycerol or $15 \%(\mathrm{w} / \mathrm{v})$ sorbitol, which were included to stabilize the bacterial cells. Thereafter, the suspension was mixed with an equal volume of autoclaved $1.5 \%$ Na-Alginate $(1,4)$. The bacteria - Na Alginate mixture was combined with sterilized talc at the ratio $1: 4(\mathrm{v} / \mathrm{v})(11)$. A wetting agent (Ca-lignosulphate) was added $(7 \%, w / w)$ to the mixture. The resulting mixture was spread thinly over a glass sheet and air dried in a laminar air-flow cabinet at $24^{\circ} \mathrm{C}$ for 1 hour to form a slightly moistened powder ( $15 \%$ moisture content). After drying, the bacterial formulation was powdered in a Waring Blendor and stored in glass bottles with lids as small volumes $(3,19,23)$. The talc-based formulations of strain Eh-24, were stored at $4^{\circ} \mathrm{C}$ for 180 days. Survival of $P$. agglomerans strain Eh- 24 in the formulations was assessed at 60 day intervals by a dilution plate method (27). There were three replications for each analysis.

\section{Orchard Trials}

All experiments were conducted in two commercial pear orchards, which were located in the Aegean (Ýzmir) and Mediterranean (Burdur) Region of Turkey in 1999 and 2000. Trials were conducted on 14 year-old trees of susceptible pear cultivars "Santa Maria" and "Akça" in Burdur and Ýzmir, respectively. In 1999 and 2000, the talc-based glycerol formulation of $P$. agglomerans strain Eh-24 was sprayed at $10^{8} \mathrm{CFU} / \mathrm{ml}$ onto pear trees in $20-30 \%$ and $70-90 \%$ bloom. The formulation was freshly prepared each year. Water treated trees were included as nonprotected controls. Additional trees were treated with the reference chemical copper-oxychloride + maneb $(0.2 \%, 37.5 \%+20 \%$ a.i.). Each treatment was applied to six trees in randomized complete blocks. Between 3 and 4 litres were applied to each tree, sufficient to cause run-off $(13,15)$. Because these assays were carried out in the orchards with active fire blight cankers, the orcherds were not artificially inoculated with E. amylovora. The incidence of infected blossom clusters was recorded two weeks after the last application of the bioformulation. In each treatment 240 clusters ( 40 blossom clusters in six replications) were examined and recorded for their blossom blight incidence. The data were analyzed by ANOVA using SPSS version 9.01 statistical software (SPSS Inc.Chicago, Illinois). Before the analyses were carried out, data on percentage of infected blossoms were transformed using the log transformations. Differences between treatments were determined by Duncan's Multiple Range Test (DMRT) at $5 \%$ significance level.

\section{Monitoring the population dynamics of $P$. agglomerans strain $E h 24$ in pear blossoms}

A spontaneous streptomycin-resistant mutant of $\mathrm{P}$. agglomerans (strain $E h-24^{\text {strR+ }}$ ) was selected to follow populations during the bloom. A bacterial suspension $\left(10^{8} \mathrm{CFU}\right.$ per $\mathrm{ml}$ ) was sprayed to run off on marked branches of pear trees in 20-30\%, and 70-90\% bloom in Santa Maria pear orchard of Agricultural Faculty of Ege university. The experimental design was a completely randomized block with 3 single tree replications. The day following the second application of strain $E h-24^{\text {strR+ }}$, nine blossoms per sampling date from three trees were collected in sterile flasks. To each flask $100 \mathrm{ml}$ of $0.1 \mathrm{M}$ Phosphate Buffer, pH:7.1 was added. Flasks were placed on a rotary shaker at $150 \mathrm{rpm}$ for $10 \mathrm{~min}$. Samples were diluted and spread on each of two petri dishes containing SNA (sucrose nutrient agar) medium, supplemented with streptomycin (100 $\mu \mathrm{g} / \mathrm{ml})$. Bacteria werte enumerated on blossoms 1, 3, 5, 8, 10, 12 and 18 days after application (22).

\section{"In vitro" compatibility of $P$. agglomerans strain $E h 24$ with copper and fungicides}

Mancozeb, Copper oxychloride+Maneb and Copper hydroxide are the most commonly used fungicides on pear orchards. In "in vitro" tests, these compounds at (3,10,30 and $100 \mu \mathrm{g}$ active ingredient per $\mathrm{ml}$ ) were incorporated in SNA medium cooled to $40^{\circ} \mathrm{C}$. Approximately $10^{5} \mathrm{CFU}$ of A P.agglomerans strain Eh 24 was spread onto the surfaces of the solidified media. There were seven replication plates for each chemical 


\section{Population dynamics of $P$. agglomerans strain Eh 24 in pear blossoms}

At the first sampling time, Eh-24 ${ }^{\text {strR+ }}$ was recovered at mean detectable population sizes of $10^{4} \mathrm{CFU}$ per blossom from nearly all blossoms sprayed with the bacterial suspension. On those blossoms on which was detected, the mean detectable population size varied from $2 \times 10^{4}$ to $1.3 \times 10^{6} \mathrm{CFU}$ per blossom within 18 days (Fig. 1). The mean population size of Eh-24 $4^{\text {strR+ }}$ on pear blossoms in the orchard increased 100-fold within 18 days after application.

\section{"In vitro" compatibility of $P$. agglomerans strain $E h 24$ with copper and fungicides}

Under the conditions of this assay, although ca. $10^{5} \mathrm{CFU}$ of Eh 24 was added to the medium, only 107 colonies were enumerated on plates that were not amended with copper or fungicides (Table 4). Low (10 $\mu \mathrm{g}$ per $\mathrm{ml}$ ) concentrations of mancozeb reduced growth and survival Eh24 "in vitro". The addition of copper oxychloride+Maneb completely inhibited the growth of Eh 24 (Table 4). Interestingly, copper hydroxide, even at a dose of $100 \mu \mathrm{g}$ per ml did not reduce survival of Eh24 in vitro (Table 4). Copper hydroxide at $10 \mu \mathrm{g}$ per $\mathrm{ml}$ reduced survival of E. amylovora (Table 5).

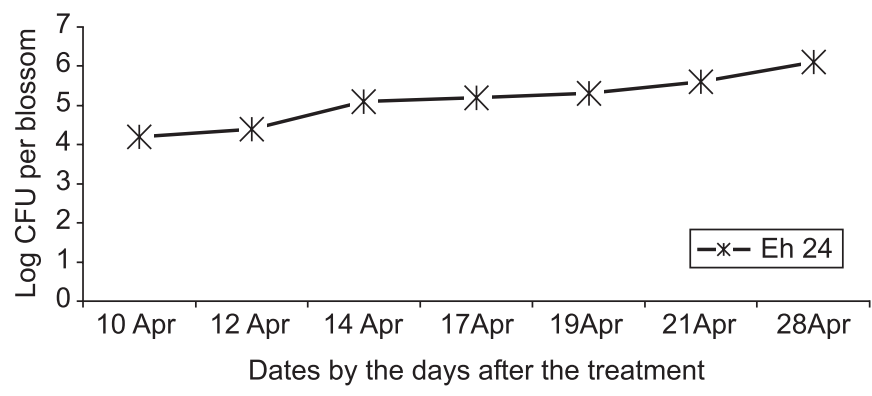

Figure 1. Mean population sizes of P.agglomerans strain Eh $24^{\text {StrR }}$ in pear blossoms.

Table 4. The effect of copper and fungicides on growth of $P$. agglomerans strain Eh 24 in vitro.

\begin{tabular}{lccccc}
\hline & \multicolumn{5}{c}{ Colony Counts (CFU per petri dishes)* } \\
\cline { 2 - 6 } Tested Chemicals & $\begin{array}{c}0 \mu \mathrm{g} / \mathrm{ml} \\
(\text { Control) }\end{array}$ & $\begin{array}{c}\mu \mathrm{g} / \mathrm{ml} \\
\mu \mathrm{g} / \mathrm{ml}\end{array}$ & $\begin{array}{c}\mu \mathrm{g} / \mathrm{ml} \\
\mu \mathrm{g} / \mathrm{ml}\end{array}$ \\
\hline Mancozeb & 107 & 110 & 27 & 0 & 0 \\
$\begin{array}{l}\text { Copper oxychloride } \\
\text { +maneb }\end{array}$ & 107 & 0 & 0 & 0 & 0 \\
Copper hydroxide & 107 & 102 & 98 & 115 & 106 \\
\hline
\end{tabular}

*There were seven replication plates for each chemical dose.
Table 5. The effect of copper hydroxideon the colonial development of E. amylovora in vitro.

\begin{tabular}{cccccc}
\hline \multirow{2}{*}{ Tested Chemicals } & \multicolumn{5}{c}{ Colony Counts (CFU per petri dishes)* } \\
\cline { 2 - 6 } & $0 \mu \mathrm{g} / \mathrm{ml}$ & 3 & 10 & 30 & 100 \\
& $($ Control) & $\mu \mathrm{g} / \mathrm{ml}$ & $\mu \mathrm{g} / \mathrm{ml}$ & $\mu \mathrm{g} / \mathrm{ml}$ & $\mu \mathrm{g} / \mathrm{ml}$ \\
\hline Copper hydroxide & 260 & 221 & 25 & 0 & 0 \\
\hline
\end{tabular}

*There were seven replication plates for each chemical dose.

\section{DISCUSSION}

Prevention of blossom infections by E. amylovora is a key in fire blight management because the cankers and bacterial ooze originating from blossom infections provide much of the inoculum for secondary phases of the disease, including the infection of shoots, fruits, and roostocks (22). Application of copper fungicides during bloom period can cause phytototoxicity on flowers and fruits. Certain strains of epiphytic bacteria, including strains of $P$. fluorescens and P. agglomerans, can reduce significantly the severity of fire blight $(7,10)$. If applied to blossoms at early to mid-bloom stage, the biocontrol agents can proliferate on pear and apple stigmas $(8,31,16)$ and exclude the pathogen from infection sites $(5,7,31)$.

Under field conditions, Johnson et al.(8) found that early establishment of populations exceeding $10^{5} \mathrm{CFU}$ per blossom of $P$. fluorescens Pf A-506 and P. agglomerans Eh C9-1 on pear blossoms suppressed establishment and growth of $E$. amylovora, thereby decreasing disease incidence. The incidence of fire blight on blossoms was reduced by about $60 \%$ with two applications of bacterial antagonists in experimental plots in the Pacific Northwest (16) and California (12). The efficacy of biological control approached or equaled levels obtained with chemical control in many of the field trials (12).

In this research, the incidence of fire blight on blossoms was reduced by about $63-76 \%$ with two applications of talcbased formulation of P. agglomerans strain Eh 24 in two commercial pear orchards in Turkey over two consecutive years. The chemical control reduced the blossom infection of pear trees by only 29-39\% in two orchards in 1999 and did not reduce incidence of fire blight in 2000; thus it can be clearly claimed that the biocontrol formulation was more effective against fire blight disease (Table 2 and 3 ).

To be effective, a biocontrol agent has to be able to multiply in the same ecological niche as the pathogen. This results in competition for space and nutrients which in itself, in some cases, is enough to confer protection $(20,31)$. It was previously determined that competition for sites and growth-limiting nutritional substrates was main mechanism by which P. agglomerans strain Eh 24 suppressed growth of E. amylovora on stigmas (18). P. 
agglomerans strain Eh 24 was well adapted to compete with the fire blight pathogen for space and nutrients (18).

Large populations of biocontrol bacteria, for example, $P$. agglomerans and $P$. fluorescens on surfaces of pear blossoms in an orchard may reduce establishment of E. amylovora $(6,10)$. For biological control to be effective, most stigmatic surfaces in an orchard must be colonized by the bacterial antagonist $(7,12)$, and the population size of the antagonists on stigmas must approach the carrying capacity of population size of the tissue $\left(10^{5}\right.$ to $10^{6} \mathrm{CFU} /$ blossom $)(30,31)$. In this research, the mean detectable population size of $E h-24^{\text {strR+ }}$ varied from $10^{4}$ to $10^{6} \mathrm{CFU}$ per blossom under field conditions within 18 days following inoculation (Fig. 1). The population size of strain Eh$24^{\text {strR+ }}$ increased about 100 -fold during bloom. This results showed that $P$. agglomerans strain Eh 24 colonized blossoms and suppressed the development of fire blight on pear blossoms effectively.

Furthermore, in vitro results indicated that copper hydroxide sprays could be applied to dormant pear trees as protective during winter treatment prior to antagonist application in an Integrated Pest Management program.

Commercial application of $P$. agglomerans strain Eh 24 for control of fire blight disease depends upon the development of appropriate formulations in which the bacterium can survive for a considerable length of time. Current formulation technology may allow for the development of commercial preparations that optimize the capacity of bacterial antagonists to survive the conditions encountered immediately upon inoculation of aerial plant surfaces $(22,27)$. One challenge in formulation technology is that during rehydration, bacterial cells may die due to osmotic shock. Gelled formulations, using polymers such as polyacrylamide polysaccharides such as Xanthan $(9,11)$, or alternatively alginate $(1,4)$ solve this problem. We used $1.5 \%$ Na-Alginate, and observed that alginate seemed to provide some protection to bacterial cells. The present study demonstrated that bacteria could survive in talc-based formulation for more than 120 days at $4^{\circ} \mathrm{C}$. Amending cell preparations with glycerol before drying in talc apppeared to increase lon-term survival of Eh 24 (Table 1). One of the key factors in survival is the preservation of residual hygrometry of about $15 \%$ in dried formulation (4). The moisture content in the bioformulation developed also was measured as $15 \%$ after drying and presumably maintained this level of hydration in sealed jars.

The use of talc-based formulation of strain Eh24, at a concentration of $10^{8} \mathrm{CFU} / \mathrm{ml}$ significantly reduced the amount of disease development in the pear blossoms under field conditions. The results of this research indicated that talc-based formulations of strain Eh24 could be effectively applied as blossom treatments to control fire blight. These observations are in agreement with those obtained by commercial bioformulations such as Blightban which are applied to fire blight in $\operatorname{USA}(7,15)$.

\section{ACKNOWLEDGMENTS}

This research was supported in part by the Scientific and Technical Research Council of Turkey (TUBITAK) and by the Ege University Science-Technology Research and Application Center(EBILTEM).

\section{RESUMO}

\section{Controle biológico de fire blight em pereiras empregando uma formulação de Pantoea agglomerans EH 24}

Controle biológico de Erwinia amylovora através do uso de bactérias epifíticas tem sido considerado um método alternativo para o controle de "fire blight". Uma formulação de Pantoea agglomerans Eh $24 \mathrm{em}$ talco foi utilizada em pereiras a $30 \%$ e a $100 \%$ de floração, em duas plantações selecionadas na região Aegean da Turquia. Os experimentos foram repetidos duas vezes (1999 e 2000) em cada plantação. A formulação de $P$. agglomerans foi aspergida nas pereiras naturalmente infectadas com E. amylovora. Nos experimentos de 1999 e 2000, a redução da porcentagem de ocorrência de "fire blight" foi reduzida aproximadamente em $63 \%$ e em $76 \%$, respectivamente. Oxicloreto de cobre + maneb foi menos eficiente na redução da infecção por $E$. amylovora do que o tratamento com $a$ bioformulação. $P$. agglomerans Eh 24 marcada com $\mathrm{Str}^{\mathrm{R}+}$ foi aplicada a 30\% e a $100 \%$ de floração para monitorar a colonização e a dinâmica da população de P. agglomerans nos brotos das pereiras. Após 18 dias, a população de P. agglomerans aumentou de $2 \times 10^{4}$ para $1,3 \times 10^{6} \mathrm{UFC} /$ broto.

Palavras-chave: controle biológico, fire blight, bactérias antagonistas, Pantoea agglomerans, Erwinia amylovora

\section{REFERENCES}

1. Bashan, Y. Migration of rhizosphere bacteria Azospirillum brasiliense and Pseudomonas fluorescens towards wheat roots in the soil. J. Gen. Microbiol. 132:3407-3414, 1986

2. Beer, S.V.; Rundle, J.R.; Wodzinski, R.S. Interaction between $E$. amylovora and E. herbicola "in vitro", in immature pear fruits and in apple blossoms. Acta Horticulturae, 151:203-204, 1984.

3. Connick, W.R. Jr. Formulation of living biological control agents with alginate. ACS-Symposium Series, 371:241-250,1988.

4. Digat, B. A new encapsulation technology for bacterial inoculants and seed bacterization. 1990, pages 383-391, in: Plant GrowthPromoting Rhizobacteria: Progress and Prospects, $2^{\text {nd }}$ Workshop on PGPR. C. Keel, B. Koller, and G. Defago, eds. Interlaken, Switzerland.

5. Hattingh, M.J.; Beer, S.V.; Lawson, E.W. Scanning electron microscopy of apple blossoms colonized by Erwinia amylovora and E. herbicola. Phytopathology, 76:900-904, 1986.

6. Jones, A.L.; Schnabel, E.L. Streptomycin and oxytetracycline resistance determinants detected among bacteria from Michigan appleorchards and their potential importance, Acta Horticulturae, 489:673-674, 1999. 
7. Johnson, K.B.; Stockwell, V.O. Management of Fire Blight:. A case study in microbial ecology. Annu. Rev. Phytopathol., 36:227-248, 1998.

8. Johnson, K.B.; Stockwell, V.O.; McLaughlin, R.J.; Sugar, D.; Loper, J.E.; Roberts, R.G. Effect of antagonistic bacteria on establishment of honey bee-dispersed E. amylovora in pear blossoms and on fire blight control, Phytopathology, 83:995-1002, 1993.

9. Jung, G.; Mugnier, J.; Diem, H.G.; Dommergues, Y.R. Polymer entrapped Rhizobium as an inoculant for legumes. Plant and Soil 65:219-231, 1982.

10. Kearns, L.P.; Hale, C.N. Biological control of fire blight by $E$. herbicola: Survival of applied bacteria in orchard and glasshouse trials. Acta Horticulturae, 338:333-336, 1993.

11. Kloepper, J.W.; Schroth, M.N. Development of a powder formulation of rhizobacteria for inoculation of potato seed pieces. Phytopathology, 71:590-592, 1981.

12. Lindow, S.E.; Mc Gourty, G.; Elkins, R. Interactions of antibiotics with Pseudomonas fluorescens strain A506 in the control of fire blight and frost injury to pear, Phytopathology, 86:841-848, 1996

13. Lindow, S.E.; Wilson, M. Population dynamics of Pseudomonas fluorescens strain A506 in pear flowers following inoculation in relation to strategies of biological control of fire blight and frost injury., Acta Horticulturae, 338:331-332, 1993.

14. Loper, J.E.; Henkels, M.D.; Roberts, R.G.; Grove, G.G.; Willett, M.J.; Smith, T.J. Evaluation of streptomycin, oxytetracycline, and copper resistance of E.amylovora isolated from pear orchards in Washington State, Plant Dis., 75:287-290, 1991

15. Norelli, J.; Aldwinckle, H. Orchard evaluation of chemical and biological spray materials to control fire blight, Acta Horticulturae, 338:363-368, 1991.

16. Nuclo, R.; Johnson, K.B.; Sugar, D.; Stockwell, V.O. Importance of secondary spread of bacterial antagonists in the biological control of E.amylovora, Acta Horticulturae, 411:297, 1996.

17. Öktem, Y.E.; Benlioðlu, K. Investigations on fire blight (Erwinia amylovora) of pome fruits (Abstr.). J. Turk. Phytopathol., 17:106, 1988.

18. Özaktan, H.; Bora, T.; Sukan, F.V.; Sukan, S.; ve Sargýn, S. Studies on determination of antagonistic potential and biopreparation of some bacteria against the Fireblight pathogen. Acta Horticulturae, 489:663668,1999
19. Petrolini, B.; Quaroni, S.; Saracchi, M.; Sardi, P. Formulations in alginate of a strain of Streptomyces: Survival and growth in the soil. Annali di Microbiologiaed Enzimologia 38:75-83, 1998.

20. Pusey, P.L. Crab apple blossoms as a model for research on biological control of fire blight. Phytopathology, 87:1096-1102, 1997.

21. Schroth, M.N.; Thomson, S.V.; Hildebrand, D.C.; Moller, W.J. Epidemiology and control of fire blight. Annu. Rev. Phytopathol., 12:389-412, 1974

22. Stockwell, V.O.; Johnson, K.B.; Loper, J.E. Establishment of bacterial antagonists of E. amylovora on pear and apple blossoms as influenced by inoculum preparation, Phytopathology, 88:506-513, 1998.

23. Suslow, T.V.; Schroth, M.N. Rhizobacteria of sugar beets: Effects of seed application and root colonization on yield. Phytopathology, 72:199-206, 1982

24. Teviotdale, B.L.; Viveros, M. Fruit russetting and tree toxicity symptoms associated with copper treatments of Granny Smith apple trees, Acta Horticulturae, 489:565-571, 1999.

25. Vanneste, J.L.; Voyle, M.D. Genetic basis of streptomycin resistance in pathogenic and epiphytic bacteria isolated from apple orchards in New Zealand, Acta Horticulturae, 489:671-672, 1999.

26. Vanneste, J.L.; Yu, J. Biological control of fire blight using $E$. herbicola Eh252 and Pseudomonas fluorescens A506 separately or in combination. Acta Horticulturae, 411:351-353, 1996.

27. Vidhyasekaran, P.; Muthamilan, M. Development of formulations of Pseudomonas fluorescens for control of chickpea wilt. Plant Dis. 79:782-786, 1995.

28. WHO. World health Organization, Technical report No 430, Geneve, 1969.

29. Wilson, M.; Epton, H.A.S.; Sigee, D.C. Biological control of fire blight of Hawthorn, Acta Horticulturae, 273:363-365, 1990.

30. Wilson, M.; Epton, H.A.S.; Sigee, D.C. Interactions between Erwinia herbicola and Erwinia amylovora on the stigma of hawthorn blossoms. Phytopathology, 82:914-918, 1992.

31. Wilson, M.; Lindow, S. Interactions between the biological control agents Pseudomonas fluorescens A 506 and Erwinia amylovora in pear blossoms. Acta Horticulturae, 338:329-330, 1993.

32. Wodzinski, V.S.; Umholtz, T.E.; Beer, S.V. Mechanism by which the antibiotic of EH 318 inhibits Erwinia amylovora Ea 273, in: Plant Pathogenic Bacteria Edited by: Klement, Z, Budapest, 1990, p.26452666. 